PARENT PERCEPTIONS OF PLAY-BASED EARLY EDUCATION IN

ABUJA, NIGERIA

by

\author{
Samantha Woolnough \\ B.A. \\ Ryerson University, Toronto, 2012
}

A Major Research Paper

Presented to Ryerson University

In partial fulfillment of the

requirements for the degree of

\author{
Master of Arts \\ in the Program of \\ Early Childhood Studies
}

Toronto, Ontario, Canada, 2017

(C) Samantha Woolnough, 2017 


\section{Author's Declaration}

I hereby declare that I am the sole author of this MRP. This is a true copy of the MRP, including any required final revisions.

I authorize Ryerson University to lend this MRP to other institutions or individuals for the purpose of scholarly research.

I further authorize Ryerson University to reproduce this MRP by photocopying or by

other means, in total or in part, at the request of other institutions or individuals for the purpose of scholarly research.

I understand that my MRP may be made electronically available to the public. 


\title{
PARENT PERCEPTIONS OF PLAY-BASED EARLY EDUCATION IN
}

\author{
ABUJA, NIGERIA \\ (c) Samantha Woolnough, 2017 \\ Master of Arts \\ Early Childhood Studies \\ Ryerson University
}

\begin{abstract}
As education in Nigeria transitions to play-based learning there is a need to understand parent perspectives as it applies to their children's education and daily experiences. This qualitative study explored 32 parents' perspectives of their children's education pre and post play-based intervention at two early learning centres in Abuja, Nigeria. An ecocultural theoretical framework was used to guide the study. Focus groups were transcribed and analyzed. The four themes that emerged from focus groups conducted with parents at both sites were: parents' reasons for using the school/care system, advocacy for systematic change, understanding play based education and the connection between home and school. Parents embodied an understanding of early childhood development and curriculum and shared a desire to see play-based learning take place in their child's classroom. Parents also shared a desire to continue to see evidence of their child's learning.
\end{abstract}

Keywords: parent perceptions of education, play-based education, Nigeria, eco-cultural theory, focus groups, pre/post intervention 


\section{Acknowledgements}

I would like to first and foremost acknowledge the wonderful people I met in Nigeria while conducting this research, who so graciously accommodated my team. I would also like to thank all of the parents who participated and shared their experiences with me. This project would not have been possible without Patricia Falope. Her efforts to revitalize early childhood education in Nigeria are inspiring and encouraging to say the least.

I would also like to thank my Supervisor, Dr. Kathleen Peets, for being there each and every step of the way. I hope to continue learning from you beyond this experience. A special thank you also to Dr. Kathryn Underwood. Kathryn supported this paper beyond her duty as second reader and continues to inspire me through her own research initiatives.

I would also like to acknowledge the School of Early Childhood Studies at Ryerson University. This opportunity would not have been possible without the support of the program and those who believed in my work as an early childhood educator and as a student.

I am very grateful to have shared this research experience with Jenna, Wendy and Adizat in Abuja. You were wonderful and supportive companions to have along this journey!

A final thank you to my family and friends for their endless support and encouragement. To my partner, Steve, for always putting things into perspective. 


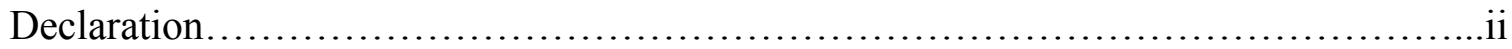

Abstract......................................................................

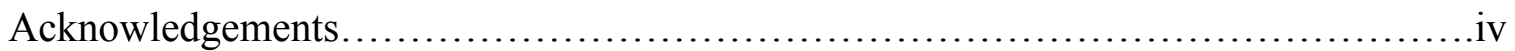

List of Tables............................................................. vii

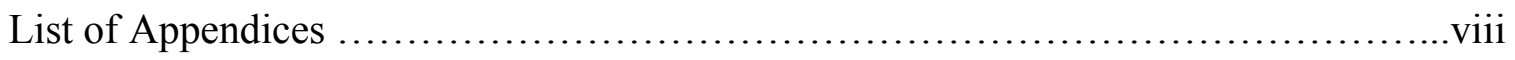

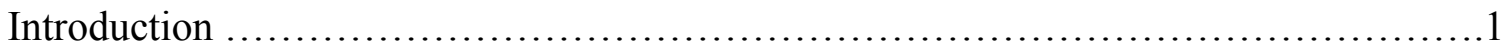

Focus and Significance.....................................................

Introduction to the larger Project............................................

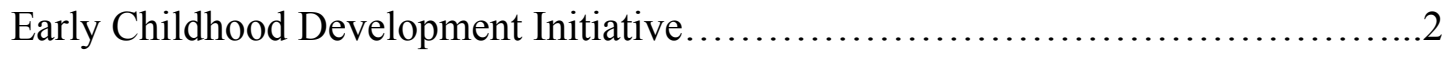

My Role...............................................................

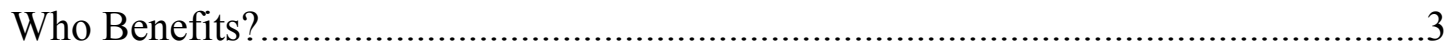

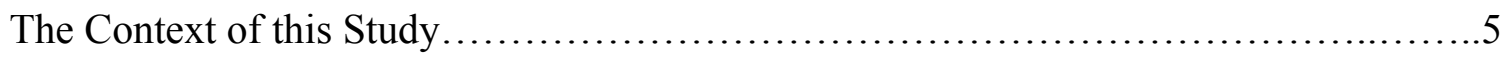

Abuja, Nigeria............................................................

Centre One: Private Christian School.......................................5

Centre Two: Government-run Creche........................................6

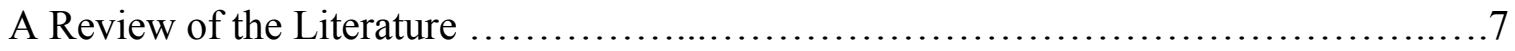

The Nigerian Educational Context...........................................

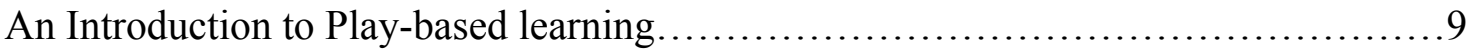

An Overview of Parent Engagement in Education...............................10

Defining Parent 'Engagement' ..................................................................... 10 
The Missing Voice of the Parents......................................... 12

The Role of the School and the Educator.................................... 14

Theoretical Framework..................................................... 17

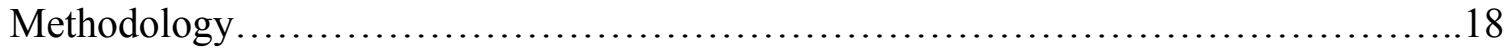

Main Research Questions................................................18

Research Approach...................................................... 18

Recruitment of Participants................................................ 19

Instruments......................................................... 20

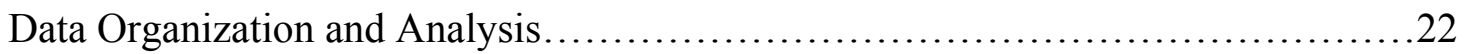

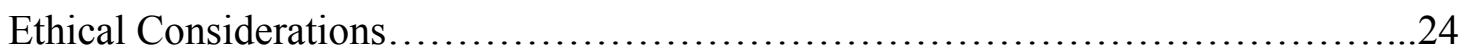

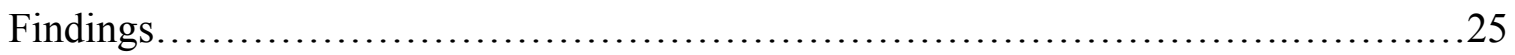

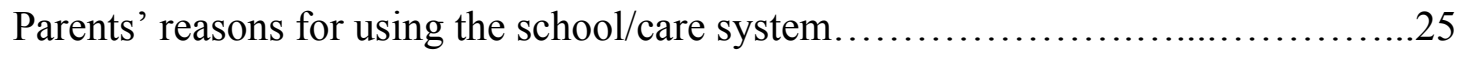

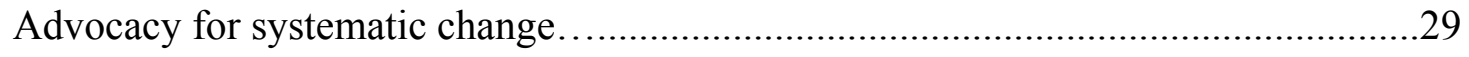

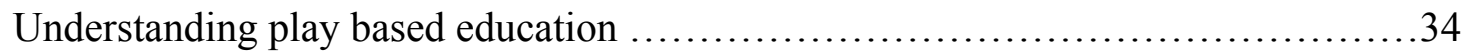

The connection between home and school................................. 37

Discussion.............................................................44

Limitations.............................................................48

Implications for practice and future research..................................50

Conclusion................................................................. 51

References............................................................ 53 


\section{List of Tables}

Table 1. Number of participants by centre and session ............................58

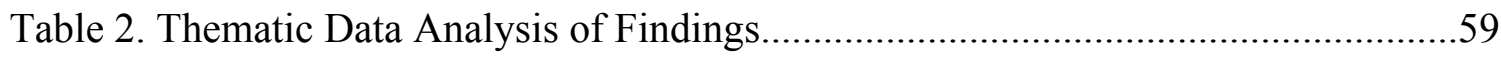




\section{List of Appendices}

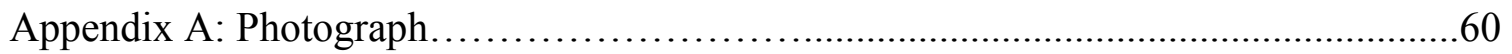

Appendix B: Consent Form...............................................61 


\section{Introduction}

\section{Focus and Significance}

The purpose of this study is to investigate current Nigerian early learning experiences and environments from the perspective of parents before and after play-based learning is introduced to their child's classroom. This qualitative study is descriptive in nature as it explores the personal experiences of parents at two early learning centres in Abuja, Nigeria. As early education in Nigeria transitions to play-based learning (see OneYear Pre-Primary Education Curriculum, Federal Ministry of Education, 2014) there is a need to understand parent perspectives.

\section{Introduction to the Larger Project}

In the months of May and June in 2016 a group of academics and students embarked on a collaborative educational project in Abuja, Nigeria. The project took place in two early learning centres; a private Christian school and a government run crèche (nursery school). Early Childhood Development Initiative (ECDI) and Ryerson University directed the project hosted by the National Commission for Colleges of Education in Abuja. The project was a cross-cultural pilot study that consisted of adapting a Western play-based method of teaching to the cultural context of Abuja, Nigeria. Participating in the larger project were local early childhood educators in the two participating early learning centres, one undergraduate student doing international field placement from Ryerson University, three master's students doing MRP research and volunteering on the project from Ryerson University, ECDI CEO Patricia Falope, and Ryerson faculty Dr. Kathleen Peets. The present study was conducted in association with the larger team project although the data for the current project was collected by me for 
the purpose of my MRP.

Early Childhood Development Initiative. Early Childhood Development Initiative (ECDI) has been working in Nigeria for four years in an attempt to revitalize the nature of early learning and primary education. ECDI supports government educational goals while also supporting communities, parents, and educators in trying to meet the learning needs of their children. Within the scope of this project, ECDI conducted training workshops for educators, head teachers, school proprietors, and education stakeholders on early childhood development, the importance of play and the image of the child. Members of the Federal Ministry of Education, Universal Basic Education Commission, UNICEF, and the National Commission for Colleges of Education were participants in the training aspect of the project. ECDI is a technical partner to UNICEF Nigeria on early childhood development and they continue to collaborate to further early childhood development in Nigeria.

Our larger initiative, in partnership with ECDI, was influenced by the Reggio Emilia pedagogical approach, which lays its foundations in collaboration and relationships with families and communities (Shipley, 2008). It is an educational approach that has been adapted to many different cultures over the years. Reggio Emilia holds the image of the child as competent, capable, and curious collaborators as they form relationships with people and materials around them (Callaghan, 2013).

My Role. I possessed a dual role during this project as I attended the trip as a Ryerson employee with experience in childcare and curriculum, but also as a Master's student collecting data for this study. In addition to collecting data with parents, I spent several days in each centre alongside the educators and aided in the implementation of our 
intervention. My support included tasks such as creating a daily routine that allowed for more exploratory play, introduced new items into classroom centres such as story books, play-dough, household items for imaginative play, construction materials, and supported the educators in implementing unfamiliar methods while still completing the work they needed to do.

Several years of experience working with Ontario curriculum documents and my understanding of pedagogical practice aided in curriculum development and implementation of a play based approach. Working with families and parents on a daily basis has shown me how influential they can be in support of their child's education. Who benefits? The larger project was conducted with the intention of supporting early learning in Nigeria. We worked directly with children and families in the community and involved them in the project, adhering to the notion that they play an important role as stakeholders in education. As we collaborated to introduce new methods of instruction, new materials, and workshops for educators, there was a significant need to incorporate the perceptions of the parents. For research purposes, we documented the process of our project, which included the adaptation of a Western model of early learning, inspired by Reggio Emilia, to Nigerian early learning environments. With the partnerships of all stakeholders and continued research, the scalability of the curricular approach to the State, even country, could be reached.

Iyamu and Ogiegbaen (2007) discuss cultural relevance in education and stated that it is dangerous to impose education that is not relevant to children's lives. Throughout our visit, we considered the cultural underpinnings of the early learning environments to ensure our intervention was suitable for the two early learning centres, 
and that it incorporated the voices of the educators, children, and parents that were being exposed to the project. International research should contribute to the discussion of issues that are unique to the country's historical and political context and raise new questions (Epstein \& Sanders, 1998).

Internationally, there has been a movement to recognize the value of play-based educational approaches to teaching in the early years as it emphasizes holistic learning for the child (Walsh, McGuinness, Sproule \& Trew, 2010). Our goal was to find ways to incorporate play-based approaches into two Nigerian early learning centres. For the purpose of this paper, the term intervention refers to the modifications we introduced to the centers including routines, environments, materials and practices. 


\section{Context}

Abuja, Nigeria. Abuja is the capital city of Nigeria. It is located within the Federal Capital Territory (FCT) State. The city houses many Federal Government buildings and Universities. Many organizations that were participants during this project and participated in the training, including UNICEF Nigeria, Federal Ministry of Education, Universal Basic Education Commission and National Commission for Colleges of Education, have offices located in Abuja, which is why this location was chosen for the project and this study. Nigeria is home to over 250 ethnic groups with Muslim and Christian religions being the major religions throughout the country. Abuja is home to a diverse combination of citizens identifying with varying ethnicities and religions, as it is the central state in Nigeria (Central Intelligence Agency, 2016).

Centre One: Private Christian school. The first centre that participated in our project was a privately operated Christian school that educated students from infancy up to grade 12. Our project was implemented in four classrooms in the school: the nursery room (036 months), the pre-kindergarten room (3 year olds), the lower kindergarten room (4 year olds), and the upper kindergarten room (5 year olds). A head teacher, whom we worked closely with and who helped arrange our interactions and access to classrooms and materials, oversaw this section of the school. High fences and guards surrounded the school; children generally entered the school on their own as parents dropped them off. Signs were posted around the school grounds that read: "Parents and visitors are not allowed into the classrooms when lessons are in progress" (See Appendix: A). Once a term parents were invited into the school for Open Day. Open Day allows parents access to the classrooms, children's workbooks, and teachers. During our visit we also had the 
opportunity to see parents invited into the school for a Father's Day concert. The events hosted by the school that we were able to witness depicted an image of how parents were being engaged by the school. At this site there were approximately 60 families with children who were enrolled in the classrooms that were a part of our intervention. Of the 60 families that were contacted to participate, a total of 26 parents offered to meet me for a focus group. Of the 26 participants, 17 were mothers, 8 were fathers and 1 was an aunt. No demographic information was collected on the parents at this site although they all spoke English with a high level of proficiency.

Centre Two: Government run crèche. The second centre that participated in our project was a crèche (nursery school) located in a government building. The crèche employed two nannies and accommodated 11 children 3 months to 2 years of age. The centre was in one room consisting of minimal materials and minimal furnishings. Parents brought their children into the centre in the morning and brought a bag that had changes of clothes and food. The two main nannies spent their days caring for the children's primary needs including diapering, feeding, sleeping and changing. Many of the parents were civil servants and worked in the building or within walking distance of the centre. Parents were welcomed into the crèche and spent some time each morning speaking with the nannies as they dropped off their children. At this early learning centre, all 12 families enrolled in the centre were contacted to participate in the study. A total of 6 parents responded to the request to participate in this study. Each of the 6 participants held full time work positions and had high levels of English proficiency. All 6 participants at this centre were mothers. No demographic information was collected from the parents at this site although they all spoke English with a high level of proficiency. 


\section{A Review of the Literature}

\section{Nigerian Educational Context}

Over the years, policies have been implemented to improve early childhood education in Nigeria. The Universal Primary Education (UPE) program was introduced in 1955 to increase access and space for children in pre-primary education, although it still faces challenges, including low enrollment rates (Ige, 2011; Sunal, 1989; Oluwafemi, et al., 2014), as the private sector has continued to dominate the pre-primary education sector (Ige, 2011; Andero, 1994). The Nigerian Federal Government introduced free and compulsory primary education for children in 1976 (Ige, 2011). Primary education begins after kindergarten as children enter the formal school system. As primary education in Nigeria became compulsory for parents, the enrollment began to increase in pre-primary programs as well, although the quality of these programs is still of concern (Ige, 2011). In 1982, Nigeria implemented campaigns and programs to support the healthy physical development of children (UNICEF, n.d.). This knowledge and strong desire to keep children healthy is still relevant in Nigerian culture and a prominent piece of their curricula. In 2004, the Federal Ministry of Education devised a strategy, which included two key areas: Teacher Education and Development and Institutional Management (Federal Ministry of Education 2014).

Nigeria has implemented two early childhood curricula to promote education and care in the early years. In 2004, the Nigerian Educational Research and Development Council (NERDC) released the National Early Childhood Curriculum for children ages 05. In 2014, the Federal Ministry of Education published the One-Year Pre-Primary School Education Curriculum developed by the Nigerian Educational Research and 
Development Council (NERDC) in partnership with UNICEF. This curriculum was established to promote school-readiness before children enter the formal school system, as more women were joining the workforce and more vulnerable children were surviving through infancy (Federal Ministry of Education, 2014). The documents state that parents do not posses the functional understanding of early childhood development and care but aim to bridge the gap between home and school to strengthen their understanding of child development and education (Federal Ministry of Education, 2014).

According to Andero (1994), Nigeria's philosophy of education is based on the integration of the individual into society, as it is important for social upward mobility. Ige (2011) discusses the economic capacity of parents suggesting that they will pay large fees to attend privately funded schools and be taught in the English language rather than join the public education system which tends to be over crowded with uneducated and untrained teachers. Ensuring that the main method of teaching in early childhood education shall be through play and that the curriculum of teacher education is oriented to achieve this has been challenging and not yet implemented (Ige, 2011). Early childhood education is meant to create a smooth transition from the home to school and to prepare the child for a successful and meaningful life in society, which should be done through exploration, socialization, and play (Ige, 2011). As most educators lack formal training or were trained as teachers for the higher grades, they tend to focus on letter recognition and counting objects, and overlook the value in social interaction and exploration (Ige, 2011).

As Nigeria's educational history does not focus on or provide resources to the early years, this provides opportunity for new research and educational agendas to establish a better understanding of the importance of the early years. Although rote 
learning is disciplined and instructional, it is important to also focus on experiences and social interaction; learning that makes sense to the child as they try to make sense of this world and those they share it with. Ige (2011) argues that the lack of a strong and unified curriculum that is monitored worsens the early childhood education climate in Nigeria as the educators are left without the proper resources and support they need to be successful and thus rely on inappropriate tools.

\section{An Introduction to Play-based Education}

Play-based education is designed to allow children and educators the ability to have agency in the classroom (van Oers, 2015). Carefully formatted environments and activities are designed to promote educational capacities in a playful and engaging manner. Developmentally appropriate practice in the early years allows for play as the primary mode of learning that still fosters independence in the child while being guided by an educator (Walsh, McGuinness, Sproule \& Trew, 2010). Children are actively engaged in meaningful activities that they have chosen in their learning environments rather than sitting idle and waiting for teacher instruction (Shipley, 2008).

Reggio Emilia schools employ a systematic approach based on active learning through play (Shipley, 2008). Reggio Emilia's approach to early childhood practices inspired the initiatives of our project outlined by Early Childhood Development Initiative, including the workshops we provided to the educators and the play environments and materials we collaborated on in their classrooms. Building relationships with communities, families, and children are at the foundation of the Reggio Emilia approach as parents are directly engaged in the operation of the program (Shipley, 2008). 


\section{An Overview of Parent Engagement in Education}

Yssel, Engelbrecht, Oswald, Eloff and Swart (2007) pose the question: what can we learn from parents from a global perspective? Education around the globe transforms and adapts in response to new research, but rarely do parents, one of the main stakeholders in education, have a voice in this research. Practices and policies should be considered to actively engage parents in their child's education. I will discuss the themes that arise in the literature about parent engagement and perceptions towards their child's education. This will set a foundation and tone for the present study. Throughout the following sections of the literature review, Canadian and other non-Nigerian or West African sources are used to provide rich descriptions and support the themes of the literature from a more universal perspective.

Defining parent 'engagement'. The term 'engagement' may focus on formal or informal activities, ranging from attending parent-teacher meetings to helping with homework at home (Lewis, Kim \& Bey, 2011). The terms parent involvement and parent engagement can be used interchangeably in curriculum documents (Wong, 2015), although some describe their potential perceived differences. Hands (2013) describes the difference between parent involvement and parent engagement stating that engagement requires a mutual agreement between stakeholders that share power, who contribute to education on a larger scale rather than simply involving parents in supporting school agendas. Engagement according to Grace, Bowes, and Elcombe (2014) is also a relationship that is built between families and services. Involvement tends to lend focus to what parents can do to support school-based initiatives (Hands, 2013). 
Epstein (2005), an influential researcher in the field of parent involvement and partnerships, defines parent involvement as 6 components; parenting (helping families in the home environment), communicating, volunteering, learning at home (homework), decision-making (including parents in school decisions), and collaborating with the community. Some practices adopted by schools may not necessarily be perceived as engagement by the parents, or may be unattainable by the family due to a variety of potential barriers, such as socioeconomic class.

Some of the benefits to parent and community engagement outlined in the literature include higher grades and successful student achievements, minimizing learning gaps, and positive social and emotional behaviours (Yssel, Engelbrecht, Oswald, Eloff \& Swart, 2007; Evans, 2013; Grace, Bowes \& Elcombe, 2014; Wong, 2015; Quezada, 2014; Leithwood \& Patrician, 2015; Gill, Lin \& Purru, 2011; Corter \& Pelletier, 2015, Preston, 2013; Underwood \& Killoran, 2012). Outside of the school meeting their academic goals and following policies, the literature does not address the benefits to children, educators, and families from being welcomed and engaged in the school community. There may be disagreement as to whose agenda is being served. Without strong partnerships, parent perspectives may differ from educators or policymakers. These voices are missing from the literature in regard to parent participation in education (Ngwaru \& Opoku-Amankwa, 2010). Parent and family engagement should be a collaborative effort between all stakeholders that is unique to the context in which it is being implemented.

Wong (2015) found most research on parent engagement was collected from within the United States. Ways of engaging culturally diverse families are becoming seemingly 
more popular in the literature (Georgis, et al., 2014). Challenging barriers to engagement and creating culturally responsive pedagogy that includes elements of both at home and in school engagement may create more meaningful opportunities for families. The literature within this review does not discuss this balance but rather separates the engagement into two disconnected spaces. Guo (2011) suggests we rethink predetermined involvement typologies such as parent-teacher interviews and create a more effective and inclusive model. Georgis, et al. (2014) discussed parent engagement as embedded in the cultural landscape in which it is situated. In North America, parent involvement in school is considered a norm whereas in many immigrant origin countries it is not expected or practiced (Guo, 2011). There is a value to be given to the cultural, first language, and religious knowledge that families possess and should be considered in a system that is still supportive of school policies, but also of family needs (Guo, 2012).

The missing voice of the parents. Although not all of the articles explicitly discuss parent engagement, their focus has been on parent perceptions of teaching practices or adapting pedagogies in their child's classroom. With this being said, many articles still rely on the author's interpretations of parent thought and there is little evidence provided that the information or opinions provided by parents have impacted the school or teaching practices at all.

Aina (2001) discusses educator concern that parents lack the ability to understand the pedagogy of their multi-age program. Although the article addresses how parents' perceptions changed over time, and they did see benefits to the program, there was no discussion about how the parents' concerns were addressed at the beginning, nor how the program adapted to suit the needs of their families. The article adopted a deficit view of 
parents, casting them as a barrier rather than seeing them as a resource. Similarly, Ayling (2015) discusses how upper class Nigerian parents prefer their children to learn to speak English and attend schools abroad as this provides them with a more elite status upon their return to their parents' social circles in Nigeria. Nigerian schools have a colonial and religious past.here is still some disagreement with some parents valuing the integration of African values and experiences and others valuing the Westernized models of early learning (Iyamu, et al., 2007). Ayling (2015) addresses the impact of colonialism, but casts the parents as choosing class over culture and makes general claims about their choices for sending their children abroad for their education.

There is less awareness of parents' role in sub-Saharan Africa compared to the United States (Ngwaru \& Opoku-Amankwa, 2010). Research suggests that speaking in the child's mother-tongue at school creates a bridge between home and school life, although parents in Nigeria show a preference for English as they associate it with social class and believe that the mother tongue language is for the home and English is for school (Iyamu, et al., 2007; Ngwaru \& Opoku-Amankwa, 2010). English is also the official language of the country. This returns the discussion to cultural relevance in educational practices and the adaptations made when there is disconnect between the perceptions of the parents and the practices employed by the educational system. Parent engagement should be shared and a mutual responsibility (Evans, 2013).

Although parents may not always be advocating for change, the parents in one study simply wanted to be heard (Ngwaru \& Opoku-Amankwa, 2010). They wanted their children to be supported, and the capacity to which they can engage to be acknowledged, as they are preoccupied with trying to provide for their families (Ngwaru \& Opoku- 
Amankwa, 2010). An accessible school that promotes parent engagement policies and provides comfort and respect to the whole family creates a community of trust and provides the children with a connection between home and school (Lewis, Kim \& Bey, 2011). To fully understand the context and needs of those in the classroom/school, resources from the community and training as to how this can be effectively done need to be considered. Hands (2013) asks what might this training look like? Due to a dearth of research into parent engagement in West Africa, I turn to work done by scholars outside of West Africa to identify roles previously established in other cultures. This investigation will contribute to the expansion of our understanding of roles crossculturally by providing West African data.

The role of the school and the educator. Much of the existing literature on this topic originates in the West, particularly from the United States. These insights, therefore, relate to the West, and may or may not relate to West Africa. It is the role of teacher training programs, such as colleges and universities, to prepare global educators to engage in partnerships with culturally diverse families (Purcell-Gates, et al., 2014). Educator training and development should not be a stand-alone event but instead a continuous process (Wong, 2015). It is easy to put statements of engagement and inclusion into policies and educational documents but educators must also be trained and supported to make the outcomes realistic and provided with the skills to put them into practice.

Leithwood and Patrician (2015) identify three parent engagement goals in their study; fostering high expectations among parents for their children's educational success, creating a platform for effective communication among stakeholders (parents, children, 
educators), and building family's social and intellectual capital related to schooling. These are suggestions in supporting parents in the home as an extension to the partnership they possess.

Barriers to parent engagement are a topic of discussion in many of the articles in this literature review, but rarely do definitions of parent engagement include parentinitiated practices (Gill, Lin \& Purru, 2011). Educators should engage in continuous learning that is reciprocal, as they learn from each other as well as the children and families in their classrooms. The school or program sets the tone for educators when trying to implement engagement strategies or initiatives. Therefore, if the school or principal is not supportive of or engaged in the initiatives themselves, it may send mixed messages to the educators and to the parents (Evans, 2013). The principal and/or school district need to provide accountability, expectations, and resources to adequately and authentically include all families (Hands, 2013). Strategies should include acknowledging the school climate and the quality of resources that are provided to and accessible for parents (Ontario Ministry of Education, 2010). The educator's ability to create a positive classroom environment can create a sense of community, identity and security for children and parents (Lewis, Kim, \& Bey, 2011). Some believe parents are the experts on their children. But while they may be familiar with their individual child, their knowledge on how to participate in their child's education may be limited due to a variety of reasons. Therefore, the onus is on the school or educators to make the first effort of including families (Evans, 2013).

Education and resources for both parents and educators should be considered when new pedagogies or approaches are being introduced that still value familial 
differences. Ngwaru and Opoku-Amankwa (2010) portray the negative relations of power that were exemplified by educators in their study, as they possessed a view that the school has superior value in educating children in comparison to the home, whereas the parents spoke highly of the school's efforts with their children. Collaboration in parent engagement efforts between the home and the school may aid in a more unified approach and understanding to parent engagement. Ige (2011) argues that stakeholders in early childhood education, including parents, school administrators and proprietors, and the government must find ways to work together to ensure an improvement in early years education in Nigeria. In contradiction to this notion of collaboration, the Pre-Primary School Education Curriculum in Nigeria states, "Many parents do not have the functional understanding of the Early Childhood Education" assuming that parents lack understanding of child development and curriculum (Federal Ministry of Education, 2014, p.vi) and minimize their potential engagement capacities. Rather than seeing parents through a deficit lens, a more collective approach that focuses on the benefits of parent engagement should be considered.

Creating an accessible environment that welcomes families is a way to show that parents' and families' involvement and engagement in the school is valued and that they have a valued role in collaboration with the educators in the school (Yessel, et al., 2007). By providing a platform for parents, as one of those stakeholders, to have a voice and be actively and meaningfully engaged in their child's education, we will begin to gain a better understanding of parent perceptions of their children's' education. 


\section{Theoretical Framework}

This study uses the lens of eco-cultural theory. Grace, Bowes, \& Elcombe (2015) describe eco-cultural theory as having a focus on the family as a whole unit of analysis; what they value and prioritize to meet the needs of the whole family within their culture on a daily basis. Eco-cultural theory focuses on ecological and cultural environments and how they influence the relationship of individuals within sociocultural contexts (McWayne, 2016). This theoretical perspective has been chosen because this study aims to understand parent perspectives towards their child's education. This study was conducted in Nigeria at two early learning centres as we collaborated on adapting their current practices. Talking with parents about what influences the daily activities of their family provides a window into culture and ecology (Tonyan \& Nuttall, 2014). The literature reviewed in the previous section identifies a lack of research that includes the voices of key stakeholders, such as parents. There is also evidence that Nigerian parents have educational preferences that are impacted by a variety of social and cultural factors that result in some disagreement on the importance and styles of education (Ayling, 2015; Iyamu, et al., 2007).

Children are typically influenced and educated by their family; their cultural values, their routines and belief systems. This influence supports my research study's primary goal to gain insight into parent perceptions towards their children's education. This theoretical framework supports all families that participated in this study, irrespective of their social status; as each family has their individual reasons to put their children in child care and their opinions as to what children should be learning and how they would like to be involved. 


\section{Methodology}

\section{Main Research Questions}

The purpose of this study is to seek out personal experiences and opinions from parents, as main stakeholders in education, within the context of two early learning centres in which we implemented play-based learning. The main research questions of this study are: What are parents' perceptions of current early learning models in their centres in Abuja, Nigeria? What do parents think about the prospects of play-based learning? How are parents currently being engaged in their child's education and do they desire to see changes? Will our intervention show a change of opinion in pre and post-test intervention groups?

Using a qualitative research approach, I hosted focus groups with parents at two early learning centres prior to our intervention and again after three weeks of implementing the intervention. By exploring the perceptions of the parents, this study aims to provide a voice to an important community that will aid in the continuous development of the early learning environments and pedagogy in Nigeria.

\section{Research Approach}

This study employed a qualitative approach to research as it attempts to uncover the personal experiences of parents through a thematic analysis of their focus group interviews. By gathering the opinions of the parents, this study aims to support the growth of early learning practices that take place within two early learning centres and empower parents to have a voice. This study is exploratory in nature as it attempts to understand the concept of parent engagement from the perspective of the parents (Creswell, 2014). These methods were chosen as eco-cultural theory has been used to 
examine social constructs such as families, school and classrooms (Tonyan \& Nuttall, 2014). A qualitative approach in which parents share perspectives through a focus-group format in semi-structured interviews enables the study to explore not only what the parents value and prioritize about their child's education, but also day to day realities that form parent of their cultural environment.

\section{Recruitment of Participants}

The study was advertised to parents by SMS (instant message) - a method that parents preferred and were accustomed to using with the school. Each family was sent home with consent forms from our team for both parents and their children that outlined the research project. Depending on the location, a date and time was set for each centre to conduct the focus group.

At both centres, the parents were invited by the research team or by members of the school administrative team through face-to-face conversation and SMS a day prior to the focus group to attend. Parents were also reminded by SMS by staff of each centre on the day of the focus group. The project was explained to participants through conversation and consent forms, and I introduced the purpose of my study at the beginning of each focus group. No incentives were offered to participate.

A total of 3 focus groups were conducted prior to the interventions, two at the private Christian school and one at the government run crèche. Each pre intervention focus group was comprised of 2-5 participants (See Table 1). During the pre intervention focus groups, all parents were invited to come back in three weeks time and participate in a follow up interview. This proved to be difficult as communicating directly with parents 
at the private Christian school was challenging as they often did not come into the school grounds and children were sent home at various times or dismissed on a bus.

A total of 4 focus groups were held during our last week in Nigeria; one at the government run crèche and three at the private Christian school. The post intervention focus groups were comprised of 4-8 participants (See Table 1). A total of 32 participants participated in the focus groups.

\section{Instruments}

Focus groups were the primary method of data collection in this study. The focus groups were semi-structured. There was a central topic to the discussion but the questions were open ended. Focus groups were used to instill a sense of group safety and provoke participants to build off one another's responses (Creswell, 2014). This strategy allows for researchers to collect data from multiple participants at the same time within an informal environment focused around a central topic (Onwuegbuzie, Dickinson, Leech \& Zoran, 2009). Participants signed consent for audio recording and were reminded at the beginning of each session that they were being recorded.

Predetermined questions were used to encourage participation and guide the conversation although parent responses gave direction to the conversation as well. Not every parent answered every question. I facilitated all of the focus groups and each one lasted approximately 30 minutes. The focus groups were held in classrooms or multipurpose rooms that were made available at each early learning centre.

I conducted the first set of focus group interviews at the beginning of our intervention at both centres. I began by prompting the parents to share with each other and myself about their experiences with their child's education and care. I concluded the first set of 
focus groups by showing the parents a 2 minute video of children meaningfully engaging with the environment, educators and peers in a play-based early learning environment in Canada, and invited them to share their thoughts on the video. This was meant to provide a general reference to play based learning and give a sense as to the types of activities and materials we would be implementing into their child's classroom. The following questions and prompts were used as a guide during the first set of focus groups:

1) Why is your child in school/care?

2) What would you like your children to do in school/care?

3) What is your relationship like with your child's teacher/caregiver?

4) What do you think about the current curriculum or model of care? (Current education model being delivered)
a. Do you know about it?
b. What do you think about it?
c. What do you think about the current learning program here?
d. What do you think they're learning?

5) What is the role of play in your child's day?
a. How much do they play?
b. Is there an opportunity for learning in play?
c. When they are playing are they learning?

6) How do you see that your child is learning? (i.e. documentation, assessments, verbal sharing, etc.)

7) What do you think about this video? 
After three weeks of intervention, during the second set of focus groups with the parents, we asked some of the questions again with minor changes to gather more information and inquire if the parents' perceptions changed in regard to current early learning models and the value of play in education. They were shown video footage of their children from that early learning centre, footage that was collected from our team during the intervention and implementation of play-based learning, and were again invited to share their opinions. Many of the parents were in agreement over the topics we discussed and often times built off of one another's responses. The following questions were asked during the second set of focus groups:

1) What do you think about the new play-based methods being introduced?

2) Is there an opportunity for learning in play?

a. Have your perceptions of this changed?

3) How do you see that your child is learning?

a. Has this changed?

b. How else would you like to be involved?

4) What do you think about this/these videos?

In an attempt to reach families who were unable to attend the scheduled focus group times, a set of the questions was provided as a questionnaire. Due to only one being returned, and the depth to which the questions were answered, this data was discarded and not analyzed.

\section{Data Organization and Analysis}

As the primary researcher, I transcribed the focus groups manually and field notes were used to aid in the process, which included diagrams of seating arrangements, 
locations, times, and amount of participants participating in each focus group. The audio data has been saved in a secure location and original audio recordings are being kept on a hard drive with my Supervisor, Dr. Kathleen Peets.

I used the constant comparative method to analyze the data for themes as developed by Glaser and Strauss (1967, as cited in Onwuegbuzie, et al., 2009). The constant comparative method was originally used in grounded theory research (Onwuegbuzie, et al., 2009). This technique was used by Yssel, et al. (2007) in their study, which also implemented focus groups with parents to further explore their perceptions of inclusion in education. This method allows for a process of inductive category coding (Yssel, et al, 2007), which begins with open coding (small units assigned to a particular code), and then axial coding (units are merged into categories), and finally selective coding which will result in a set of themes (Onwuegbuzie, et al., 2009). This method is particularly appropriate as my study conducted multiple focus groups and allowed me to assess cross-group saturation (Onwuegbuzie, et al., 2009). As this study was guided by eco-cultural theory, the analysis of parent perceptions allowed for the development of themes that were meaningful to parents and influenced by parents' day to day decision making for the family (Grace, Bowes \& Elcombe, 2014).

The process began by reading the transcripts in their entirety. The transcripts were then read again and small units of text were assigned codes. Codes were assigned based on repetition, importance in relation to the theoretical framework (deemed by myself), and whether or not they were related to a theory or concept. The codes were then organized into categories to help conceptualize the data. This was completed for both sites. Theoretical linkages were identified within the categories, which allowed for 
reduction and resulted in the themes that emerged from the data.

\section{Ethical Considerations}

My Supervisor, Dr. Kathleen Peets, applied for ethics for our entire project with Research Ethics Board at Ryerson University, and this study was included in that proposal. Each family was provided with a consent form that outlined the researchers involved in the project, the institution we are aligned with, the purpose of our studies, the benefits and risks to participating, a guarantee of confidentiality, focus group script/questions and contact information (Creswell, 2014). Communication with families was challenging at times and although they had this consent form I found that many parents were still unsure of the nature of our work. I was careful to explain the purpose of our project to each parent and specifically the nature of my own research and what it was being used for.

The CEO of ECDI, Patricia Falope, acted as a cultural liaison as I do not share the same cultural background as the families we were working with. She helped prepare for the formalities of the focus group, such as the time of day each was held and when to offer food, to ensure the parents were comfortable. 


\section{Findings}

In this section the data will be presented by theme; including data from both early learning centres during pre and post intervention focus groups. While analyzing the data from the focus groups, four themes emerged. These four themes are: parents' reasons for using the school/care system, advocacy for systematic change, understanding play based education and the connection between home and school. Each of these four main themes is composed of two to five subcategories. Although certain questions elicited responses specific to these themes, on some occasions it was mentioned throughout the focus group at other times. For this reason, the findings from pre and post intervention focus groups will be presented together. There were more participants and more focus groups conducted at the private Christian school, which may have elicited increased frequencies at this early learning centre although there are still notable differences between the two centres.

\section{Reasons for using the school/care system}

Parents at both sites discussed the importance of choosing each site for school or care, primarily during the pre intervention focus groups when asked: "Why is your child in school here?". Although primary education is mandatory in Nigeria, more than one year of pre-primary education is not and therefore parents varied in their motivating reasons for enrolling their children at these particular early learning centres at an early age. The most significant categories that arose from this theme were using the system for learning and/or education purposes, social interaction and convenience. Using the school/care system for reasons of learning and/or education was most prevalent at the 
private Christian school whereas convenience was more prevalent at the government run crèche.

\section{Learning/Education}

During the pre intervention focus group at the private Christian school site, parents expressed seven times that the primary reason their child was enrolled at the school was to gain academic knowledge, particularly from a young age. One parent stated:

Why is my child in school here? I think as a parent, every parent wants the best for his or her own child. And after they came here because of the environment, so I decided to let my son enroll and as a child should start from a good background so when you train your child well they will not depart you. So education I think is the most important, you should really start not the best thing just secondary school, but from nursery and primary, if the child is sound from nursery and from primary, I don't think you would have problem that much and you are training him up.

When discussing the utilization of the school system, another parent discussed the role of the teacher to educate the child and meet their individual needs:

The most important is to get education. That is the main reason why I send the children to school because this experience, I can not handle everything they do so push them to professionals can actually give them what they need at each stage. Do you understand? Because age by age, what uhm a two year old who will make, would be dreadful they will handle them 
under you so each child has his or her own needs that teachers will be able to meet but particularly with each child. I don't know whether you understand that.

At the Government run crèche, the importance of learning and skill building was discussed four times. One parent stated:

Most importantly, learning (P3: exactly), learning because during the weekends I play lot uhm Barney videos, especially Barney videos, I have discovered my daughter learns a lot from Barney videos, she can sing, even if she can't pronounce the words right now because she is still little but she can mumble almost every song in Barney, so I want them to learn. I've actually advise them to get more videos right now to teach them how to say their numbers and alphabet (P3: exactly). It's more important.

During the post intervention focus groups, reasons for using the education system were discussed less frequently. As many parents at the private Christian school did not participate in the pre intervention focus group, the questions were asked again during post intervention focus groups and three of twenty-one parents stated the importance of learning and education.

\section{Social Interaction}

In addition to acquiring academic knowledge, at the private school, parents also discussed the benefits of social interaction with other children while in school two times during the pre intervention focus group:

I would like them to uhm learn their academics uhm learn to interact with others, children their age, learn to uhm socialize I mean with good habits, 
good speech, uhm good diction, I want the children to come out of school having learnt the basics that you need to in elementary school, so that's what I want them to learn.

During the post intervention focus group, parents at the private Christian school mentioned the benefits of social interaction in a group educational setting one time. Within the responses from parents at the Government run crèche, the benefits of social interaction were cited two times and again, this topic was not discussed during the single post intervention focus group.

\section{Convenience}

At the private Christian school, only one of the four parents stated that they utilized the school system for reasons I have categorized as convenient. It should also be noted that throughout the focus groups in entirety, this is the only parent that discussed Religion at the Christian school. She stated:

My own kids, my child is here because he's actually my nephew and is staying with me right now, his mom is in school in the UK so he has to come and stay with us. His dad is around but because his work takes him out of town, so he lives with me. And then his cousins, my own children are here so automatically he came in here...And then I know the owners of the school too, they both essentially because the school is also a Christian school, there are few Christian schools.

At the government run crèche, five times parents spoke about using the care system for reasons of convenience during the pre intervention focus group. Location and 
proximity of the centre was central to this category as well as living within a dual income family. One parent stated:

Uhmmm for me, 1. I, it's convenient for me, I'm a working mom, that doesn't mean I don't love her enough to stay at home but I have to work. Then I think this place is safer for her to be down here with children and uhm more than one nanny then keeping her at home with just one nanny. During the month various risk and issues with parents I've heard cause of other nannies and uhm beating of the children, not feeding them properly, not taking care of them, leaving them at home, but here you can walk into the crèche without calling any nanny to check in on your child to make sure they are doing what you want them to do, and my office is close by, it's 3 minutes walk, so for me it's convenient, I can check up on my daughter anytime, because my home is like 45 minutes drive, so the risk is actually less for me here, then leaving her at home, so that's why she's here.

\section{Advocacy for systematic change}

Throughout both the pre and post intervention focus groups, parents at both sites discussed the need to change the way the current program was operating either in regard to teacher training or the current teaching processes/curriculum. Both categories were predominantly discussed at the private Christian school although parents at the government run crèche cited their desire to see changes to the current program/curriculum a significant number of times during the pre intervention focus group. 


\section{Teacher Education/Training}

At the private Christian school, the need to educate the teachers and the important role that the teachers play was discussed six times. One parent, when discussing the prospects of play based learning, stated:

Honestly. It's just that the way, they need to teach the teacher, if you don't teach the teacher they will just do the old thing, because they will say oh they are playing there now and say they have done their work but you need to be actively involved.

Similarly, after watching the video of children in a play-based classroom in Canada, one parent said:

That is my idea of teaching now, when you see that you think they are playing but the teacher is actually teaching. I was telling you about it, you want to introduce the play method into Nigeria you need to teach the teacher very well...

At the government run crèche, the level of teacher training was cited three times. There was an awareness that the nannies did a good job but were uneducated. One parent said:

... I'm very much aware, I can only speak for myself that the women we have here, the nannies we have here, are not well educated, okay? But, in taking care of children, they are good, so they might say something that is not really correct and my daughter will say too which means she learnt it from them. You understand what I'm saying? 
During the post-intervention focus group, the parents at the private Christian school discussed the level of teacher training another six times. While the pre intervention discussion focused more around the need for trained teachers to implement a stronger curriculum, the post intervention discussion focused on the need to sustain our intervention and the teachers' abilities to collectively adapt to change. Parents were concerned that the teachers would not be able to keep up with our program and that there needed to be a system in place to monitor and encourage process.

\section{Curriculum/Program}

During the pre intervention focus group at the private Christian school, the current curriculum/program, or advocacy on behalf of a revised one, was discussed seventeen times, making this category the most frequently occurring in the data set. One parent, who identified experience with curriculum development (see quote below), stated the school was really trying and would eventually reach a desired curriculum but they were not there yet:

(laughs) you mean for this school? (Yes) We don't really want to go deep into it, you know. We know there is a ... professional arrogance, I am sure you know that and when you are into something and uhm your child is in the system where you yourself are developed curriculum you always see things that are wrong. Frankly speaking, in Nigeria we've not got the early years system properly. Frankly speaking, and uhm, but the school is really trying the school is really trying I've gone to schools and worked in big schools in Abuja so I know they are really, really trying but for early years I was like the first meeting they spent with us because in 
(place) this play and style of teaching the children that is what is the others need that is what helps the communities you know develop and to help the child. But in Nigeria when I went for my child's uhm the last time they had this Open Day and the teacher wanted to impress me and I said don't impress me don't impress me for me I am not after my child reciting $1-20$, I don't want that. For me I am not after my child can say states and capitals that doesn't get me, I need my child to grow to learn you know don't force everything on my child that is why when I am teaching my child I go to a particular space I am not a total fan about Maria Montessori but there are so many things I love about her curriculum so for the curriculum I don't want to say to deeply things, we are going to get there but we are not there yet.

During the post intervention focus group, the curriculum was cited six times. Parents expressed a supportive stance of the new approach that was being introduced while also expressing how cumbersome the current curriculum is. Many parents expressed a desire to see more hands on experiences that set them up for lifelong success:

Okay for me what I want my child to actually do is beyond just the books. I want my child to be able to have hands on what they do, what they learn, because to me that is the best way for me.

Parents at the government run crèche also discussed the current programming and the present curriculum and this was cited six times during the pre intervention. Parents 
were all in agreement that the nannies took on more of a caring role and less of an educational role in the centre. One parent stated:

It's okay for now but I still want them to improve (P3: exactly) because I actually asked certain questions and for some crèche they are infusing the primary school and nursery school environments. They teach more. Some babies already learning, they are already able to say their Abc's and 1-2-3 to ten.

Parents focused on basic educational milestones that they expected to see infused into the program rather than what they were currently witnessing. One parent stated:

Okay, I think uhm the learning process it's not really good, because as a child is growing up they should really kind of learning, educational, introduce not just going to eat and sleep and watch television, at least from one year above they should be kind of training baby, employ somebody that would be pushing them truly basic steps maybe from learning alphabet or figures or 123 at least will improve so that when they are leaving here to a normal school it won't be that they will be starting from scratch.

During the post intervention focus group, the parents continued to express positive feedback towards the methods and materials that were being introduced but there were no mentions of advocacy for change in relation to the curriculum. 


\section{Understanding of play based education}

Parents were asked to describe their understandings of play and whether or not they saw a potential to learn while playing. Some parents described play naturally within other responses. Initially, there seemed to be an understanding that play and learning were conducted separately. Although, as they asked more questions about our project, and saw and spoke to their children throughout the intervention, their perception shifted into a supportive stance toward the curriculum. The two categories that were identified within this theme are learning through experience and play and learning. Parents at the government run crèche predominantly spoke about learning through experience during the pre intervention focus group whereas parents at the private Christian school predominantly spoke of the relationship between play and learning during both pre and post intervention focus groups.

Learning through experience

In many circumstances, parents described children engaging socially and learning from one another, as well as engaging in an experience that hurts them and learning from that experience. At the private Christian school, learning through experiences was cited once during the pre intervention and nine times during the post intervention focus group. During pre intervention, one parent said:

... Before now, before I went on the Montessori course, you know, I never allowed him in the kitchen, when he's in the kitchen I keep asking him to leave the kitchen but now I allow him because what I was taught in the Montessori education is that a child wants to work, the child wants to do what your doing so you allow him to do what he wants to do, so 
with that now he is able to do a lot of things, he can - he uses his potty, he drains his potty himself, he cleans it himself, he does lots of things he wants to once I ask the older cousin to get something, he wants to go and get it he says 'no no', he wants to go and get it so uhm play is actually important because children learn through play, they learn that things that hurt them they get injured they learn from those experiences so it is extremely important that play is part of uhm the learning experience of a child.

At the government run crèche, learning through experience was cited four times during the pre intervention focus groups and two times during the post intervention focus groups. Similar to the other site, many experiences that were mentioned by the parents were related to safety and learning life skills/lessons rather than acquiring academic knowledge.

\section{Play and learning}

In regard to play and learning, although initially during pre intervention focus groups, some parents identified them as separate, many were in agreement that learning could take place while they are playing. During the pre intervention, conversation in regard to the understanding of play and learning was cited four times at the private Christian school. When asked about play and learning one parent expressed belief that parents will want to see evidence of academic achievement to be supportive of playbased learning, she said: 
It's good, it's good, it's good. But in Nigeria, they won't understand it to, because I see too much of play. But if results come out of it, people will understand.

While slightly hesitant at first, other parents saw the value in play, although they felt this related to the gender of the child and the amount of energy they possess: So I think play is important, at home my nephew plays a lot. He is very busy. He is a boy. He plays a lot, very playful, incidentally he is the only boy, all my children, there is five, are all girls, so he plays a lot, climbs things, wants to do things.

Although there was positive reactions to the notion of play based learning and children being able to engage with materials in a meaningful way, there was still some disconnect between play and learning that seemed separated to some parents. When discussing the introduction of more time spent outdoors and allowing the children to exert some energy rather than spending all of their time in the classroom, one parent asked:

Let me ask anyway, when you take the children to play as the very first thing to do in school, do you think the energy they have dispensed will make them tired?

During the post intervention focus group, parents had more positive reactions when asked if they thought learning and play happen simultaneously but still had a desire to see evidence of learning taking place. Learning and play was cited eleven times during the post intervention. One parent said: 
Yes of course. This is the challenge if we are trying to say, more play. Because there are some parents who want as much as possible to have a balance so you don't want to have an instance when they are just playing and not they're learning but if it's play that develops them learning wise then fine but I really don't see play in what they are doing in the curriculum, I wouldn't say that. So if that can be improved then, have play along with learning that will be good but we need to have a balance.

At the government run crèche, play and learning was cited three times during the pre intervention focus group and two times during the post intervention focus group. Similar to parents at the other site, one parent expressed play in relation to the amount of energy but also how her child interacts with materials.

For my daughter she does, she's pretty active, very active, on the active side, so uh $100 \%$ of the time when she is playing she is learning. She touches objects, she picks them, she drops them, she likes colours, she listens to what people are saying.

\section{Connection between home and school}

The final theme that emerged from the focus groups with parents is the connection between home and school. This theme developed from discussions around how parents are involved or engaged in their child's education. The categories that formed this theme include making learning visible to the parents, environments in which learning takes place, communication between parents and educators, relationship between parents and educators, and access to the program. Making learning visible and access to 
the program were predominantly discussed at the government run crèche whereas environment, communication, and relationship were discussed more frequently at the private Christian school.

\section{Making learning visible}

During the focus groups, parents were asked how they saw their children's learning or progress in school. Parents at both sites had different perspectives on access to their children's classroom/school environments. During the pre intervention focus group, visibility of children's learning was cited four times. One parent at the private school said: "Learning is something that we see when the child is back from school", referring to interactions with or observations of the child that demonstrated new skills, language or knowledge. One parent said: "Yeah, you help them and assist them for their homework".

Similarly, at the government run crèche, parents also discussed the visibility of their children's progress at home and observations and interactions with their children when at home:

For my daughter I interact with her, from her daily activities, from her attitude to me, to other people, to people at home, the people at crèche, I think everything concerning her shows me if she is progressing or not, the way she eats her food also tells me if her progress has been made or not, the way she reacts when she sees me in the evening tells me on a daily basis if she is actually progressing or not. 
During the post intervention focus groups, making learning visible was cited three times at both sites. There was no discussion at either site about being engaged directly in the classrooms or school.

\section{Environment}

Throughout the focus groups at both sites, the environment was mentioned several times, particularly the home or classroom environment. During the pre intervention focus groups the environment was cited five times at the private Christian school and seven times at the Government run crèche.

At the post intervention focus group at the private Christian school, the environment was cited two times. One parent stated that the school environment is not always accessible, but that they do host one "Open Day" each semester for parents to visit the school.

...the school provides a platform for that, they have 'open day' when you can go to the classroom, see what they are doing, go through their books, because at home you only get to see the homework, but the open day you get to go through classwork as well and you ask questions as well.

There were also two citations at the post intervention focus group at the government run crèche but one parent expressed the desire to bridge the two environments of home and school to minimize gaps for the child:

...so I think they are doing good but they should just tell us so we can continue the learning process at home so that we don't create that gap so on weekends we can also know how to keep your child or baby's on track. 


\section{Communication}

Communication in the context of this study was used to describe the interactions, either verbal or written, between parents and teachers or school administrators. During the pre intervention focus groups communication was cited five times at the private Christian school and four times at the government run crèche. During the post intervention focus groups it was cited twelve times at the private Christian school and one time at the government run crèche. At the private school, most parents mentioned communication with teachers consisting of expression of concerns that that either the parent had with the school or that the teacher had about the child. Although they do not have many opportunities to speak with the teachers, one parent mentioned a parent meeting platform that is held at the school.

...there is also a forum for parents and teacher, PTFF, that is what they call it and uhm parents teachers friends forum.

Another parent also shared the use of a communication book to ensure that he was able to remain in contact with the teacher as he is not usually at the school to speak directly with her.

We communicate especially through communication book even though in the last two months I have not written anything in the communications book but I strive to ensure that every thing she said for us to do I try to do them especially working on assignment, homework.

At the government run crèche, the communication was more casual with the nannies as the relationships were described by parents as more positive and comfortable. 


\section{Relationship}

Relationships were described at both sites as being positive although they were more familial in nature at the government run crèche whereas they were described as more cordial at the private Christian school. During the pre intervention focus group, relationships were discussed five times at the private school. The parents expressed that they felt as though the relationship had to remain positive as their children spend their days with them:

So our relationship is respect our teachers because most times our children spend times with them we are not there but they take care. We send money to them, we are not there so we should have a good relationship with the teachers so that they will be able to take care of our children as well.

Although there was a desire to remain cordial, there was still no hesitation to communicate with the teachers or school administrators if the parents' have any concerns:

It's cordial but I won't say because I'm cordial with my child's teacher when I notice something that is wrong I won't you know let them or these particular people. It's cordial because you can't fight with your child's teacher, you can't be in any mood with your child's teacher, you are placing that child in their hands, we are all humans so we just have to as much as possible be friends with them and then also let them know when they are not getting some things right. 
At the government run crèche, relationships were discussed two times at the pre intervention focus group. The parents that participated shared very positive representations of their relationships with the woman that worked at the crèche, and sought advice from them not only in respect to education but also parenting:

We have a good relationship. They are older women so I see them as mothers. Unfortunately my mom is late so most of time if I have any issue concerning my daughter, I'm coming to them to ask them certain questions so they are more experienced, I feel comfortable with them as mother and daughter and granddaughter relationship that is what we all have.

\section{Access}

As mentioned previously, parents at either site had different experiences in regard to accessing to their child's classroom and learning experiences at school. The entrance of the private Christian school is gated and signs are posted around the school to notify parents that they are not welcome to enter the classrooms during class sessions:

There is restriction on that. You know that parents don't come in during classes so it's not allowed you can't just go in you have to wait for opportunity or after school when you pick up your children but for you to walk into classroom when classes are going on (you can't do that), no.

At the government run crèche, parents are always welcome into the classrooms and generally spend time at drop off and pick up as well as throughout the day, as they work close by. Because the children are mostly under the age of 2 at the crèche, many parents discussed access in terms of entering the classroom to breastfeed. During the pre 
intervention access was discussed two times at the private Christian school and six times at the government run crèche.

During the post intervention it was discussed six times at the private Christian school and not discussed at all at the government run crèche. Although barriers to inclusion are identified, many parents still felt that the school made a positive effort to include the parents and allow access should they have any concerns. One parent said:

The way I see uhm while I can say for a fact what I like about the school is they allow us to have access to the teacher like phone number so if I have a concern, if someone pick on my child and my child comes home and I see something is wrong I call the teacher and they answer. We talk. Sometimes when I pick up, most of the time I have a few seconds to chat how they go how you going. If the teacher have a concern they show, so that person tell me about the day, how it is improving, just to quickly chat when I pick him up, I try to do that often.

In summary, there were minimal differences between pre and post intervention focus groups at the early learning centres. The four themes emerged throughout both pre and post intervention focus groups. This may have been due to the variance in participants, which prevented collecting data that captured a shift in perception. The initial plan was to include the same group of parents at both the pre and post intervention focus groups, although due to various reasons, such as parents' availability, each focus group was held with new parents with only two that were available to attend both. This also meant that the same questions were being asked at many of the focus groups, which may have also elicited similar themes within the discussion. 


\section{Discussion}

In this section I will discuss the findings in relation to the conceptual theoretical framework of the study as well as the questions I was seeking to answer. The purpose of this study was to seek out personal experiences and opinions from parents, and to provide a voice to parents as important stakeholders in education. The questions this study sought to answer included: What are parents' perceptions of current early learning models in Abuja, Nigeria? What do parents think about the prospects of play-based learning? How are parents currently being engaged in their child's education and do they desire to see changes? Will conducting pre and post intervention focus groups present a change of opinion?

The reconceptualization of early childhood education is timely and approaches should acknowledge cultural diversity and the pressures on families for their children to be successful (Shipley, 2008). The social and cultural environments that children encounter everyday affect their experiences and development. Parent's day-to-day choices guide the structure of their children's day and the routine that they will encounter. This includes the environments their children are exposed to and the encounters they have from the moment they wake up to the moment they go to sleep again (Gallimore, Goldenberg \& Weisner, 1993). The eco-cultural conceptual framework employed in this study links daily activity to larger cognitive constructs, such as values and goals held by parents (Tonyan \& Nuttal, 2014). As parents expressed learning and education as being the most prominent reason that they were using the school/care system, there is a desire to have academic achievement as a primary objective to sending their children to school every day. 
The most common themes that emerged from the data were focused around curriculum, the parents' knowledge of the curriculum and their understanding of playbased education. Parents seemed to have a strong understanding of what was currently being implemented, but questioned the purpose of several components of the current education their child was receiving. At the private Christian school there was a desire to see children learning in a way that allows them to use critical thinking skills rather than rote count from 1-100. One parent referred to rote learning as the 'cram, jam and drop it' approach implying that they learn the task being introduced by the teacher but it has no practical value to them and they lose the knowledge when they do not apply it in their day-to-day life or experience any of the learning hands-on. Ige (2011) identifies that in many kindergarten classrooms, they are not taught much beyond identifying shapes, letters, and counting numbers. The current findings suggest that the parents are not in full support of the current curriculum being implemented. At the government run crèche, parents described a desire to see more of an academic presence in their child's day. They were less concerned about rote learning but observed more of a caring role that takes place in the crèche. Ige (2011) also discusses that most crèche centres provide children with custodial care while their parents attend work, but very limited learning takes place. No one seemed displeased with the care their children were receiving, rather they made very positive remarks, although they possessed an understanding that children as young as their own still had the ability to learn from their caretakers.

The most significant disagreement parents had was in relation to the relationships the parents possessed with their child's teacher. While some parents' believed it was important to maintain a positive relationship with the educators, others did not see the 
need to do so. As most parents did agree about the benefits to play based learning and the need to adapt the current early learning frameworks in Nigeria, there was no significant negative response to the intervention that was implemented. The major concern that arose out of both sites was the desire to have accountability in having the teachers continue the practices and be provided with the tools to do so.

As we continue to move towards an adapted early years curriculum to strengthen primary years of education in Nigeria, there is a necessity to include parents in this discussion and process. By collaborating with participants in future and current research initiatives, we hold ourselves, as academic partners, accountable to ensuring the successful restructuring of education in a meaningful way. The potential capabilities of youth in Nigeria need to be harnessed to promote participation in productive capacities that contribute to Nigeria's economic development (Central Intelligence Agency, 2016). Parents in this study acknowledged that a solid educational foundation begins in the early years and it is not only the higher levels of education that prepare a child to be successful.

Interestingly, parents in this study discussed the value play-based learning possesses for future educational aspirations and the child's ability to practically understand and apply their learning to become global citizens. The current pre-primary curriculum in Nigeria discusses the shift to a more holistic approach that includes play experiences but explicitly states that parents lack fundamental understanding of child development and early childhood curriculum. The government sought to remedy this lack of understanding by creating an early years curriculum with intentions to close the gap between home and school readiness (Nigerian Research and Development Council, 2014). The small population that participated in my study does not allow me to generalize 
to a wider population although the parents I spoke with appeared to have a strong desire to see change to what was currently being implemented and, with minimal introduction to the notion of play-based learning, saw the benefits that it could provide to their children. They also shared a desire to have resources at home to promote and enhance the learning that takes place at school/care, which would also aid in closing the gap between home and school while capitalizing on the role of the parents and the resources they could in turn share with the school.

The parents, although supportive of the approach to play-based learning, still needed reassurance that the educators would be provided with resources to support their children's learning and that there would still be academic components and evidence of their child's learning. Parents in this study possessed a strong desire to have evidence of their children's learning - they wanted to see results that play-based learning would allow their children a better opportunity to become successful adults. Parents at both sites stated that daily interactions with their children were the best determinants of seeing what their children had been learning. As I had an active role in implementing the play-based intervention at both early learning centres and conducted the focus groups with parents, which included videos demonstrating play-based learning, I was able to see the shift in their perceptions of understanding the value of play-based learning. There was a notable shift from before to after the intervention in their support for the future of play-based learning in their child's classroom. 


\section{Limitations}

Time. This study possessed several limitations. The most substantial limitation was timing. As the team's stay in Nigeria was only a few short weeks, we were very limited on time spent at either site. The pre intervention focus groups were conducted at the beginning of our trip although due to the length of stay, the post intervention focus groups took place only three weeks later. This restricted amount of time between the focus groups limited parents' exposure to the intervention. This limited amount of time also hindered us from being able to delve deep into each individual classroom in regard to the intervention. Only one of the parents acknowledged changes to the environment in the classrooms during the focus groups but many of them needed an explanation as to what we were doing and how we planned to continue supporting the change. Access. Access to the participants was also a challenge as I had limited direct contact with the participants. At the private Christian school, I was not the one directly interacting with the parents prior to the focus groups. I had to rely on the Head teacher to coordinate a time for us all to meet. There seemed to be misconceptions as to what we were doing as the setup of the space we were provided was not initially conducive to a focus group and none of the parents were really sure why they were there. The pre intervention focus group was held on 'Open Day', which meant that many parents were already missing work to meet with their child(ren)'s teachers, and did not have much time to wait and speak with me.

At the government run crèche, similar barriers were faced as many parents had busy schedules and it was challenging to coordinate a time to meet with everyone. There were misunderstandings as to what the purpose of our visit was and what we would be 
doing with our data. One parent expressed her desire to not have her child on video, as she was aware of the way the 'Western world' portrayed children from Africa and it was not an accurate depiction of her family. The research team clearly articulated the purpose of our study and the way in which we intended to disseminate our findings to mitigate this misconception.

Generalizability. As the research was conducted over a short period of time in Nigeria, generalizations drawn from the focus groups could not be returned to the participants for clarification or elaboration. As only 32 participants were included in this study from two early learning centre's in the Capital Territory of Nigeria, it would be inappropriate to generalize these findings beyond this population. Future research could include a broader range of locations as well as a longer timeline.

Reliability. Only one method of data collection was used in this study, although each focus group was provided with the same instructions and the same general structure of questioning. As most of the participants did not participate in both the pre and post intervention focus groups, this may have contributed to inconsistent findings as it is challenging to determine if their perceptions really changed throughout the process of implementation. 


\section{Implications for practice and future research}

The aim of this study was to address importance of parent engagement in education and to contribute to the limited research that emphasizes parent perceptions of their children's education in Nigeria. In the months following this study, one of the centres hired a parent liaison to strengthen their parent engagement strategies and ensure their efforts were in collaboration with parents and families. As Early Childhood Development Initiative broadens the scope of their work, it would be optimal to continue to gain perspectives from other communities as well.

Many parents wanted to discuss how the research team was going to maintain the changes we had implemented into the classroom rather than openly and deeply share their perspective on the prospects of play-based learning. Maintaining communication with parents during this transition will be optimal to a quality program and rich engagement with the community.

This research is timely as Nigeria continues efforts to strengthen their early years programs. It would be interesting to know if children's recollections of their experiences separate play from learning, and how educators perceive implementing a play approach to their practices. 


\section{Conclusion}

The purpose of this study was to investigate current Nigerian early learning experiences and environments from the perspective of parents. This cross-cultural pilot study consisted of adapting a Western play-based method of teaching to the cultural context of Abuja, Nigeria. The data for this study was collected before and after the playbased intervention was introduced in the participating early learning centres. This intervention included elements of play-based curriculum including creating daily routines that allowed for more exploratory play, introduced new items and materials into classroom centres and supported the educators in implementing these new practices. Our intervention was influenced by the Reggio Emilia pedagogical approach, which lays its foundations in collaboration and relationships with families and communities (Shipley, 2008). Providing parents an opportunity to share perspectives through a focus-group format enabled the study to explore not only what the parents value and prioritize about their child's education, but also day to day realities that form part of their cultural environment. There are many unknown factors within the nature of cross-cultural research, therefore an emergent design that allowed for flexibility was employed (Creswell, 2014).

As education in Nigeria transitions to play-based learning there was a need to understand parent perspectives as it applies to their children's education and daily experiences. In this study, parents demonstrated a critical awareness of the curriculum and a desire to see change that would benefit their children and support their lifelong learning. There was overall support amongst the parents towards play-based education as long as an academic component was clearly articulated and observed. Ige (2011) argues 
that creating smooth transitions between home and school, producing a unified curriculum that promotes play-based learning and training educators to engage children and families in meaningful ways will benefit the early years education system in Nigeria. Parents in this study expressed similar beliefs. Now that we know that the parents' perspectives are consistent with the literature and the notion of play-based learning, there are signs that there is a real shift in pedagogical focus from rote learning to play-based learning in Nigeria. The consistency between Ige's perspective and the parents, and the rich perspectives that the parents brought to the focus groups, belie the assertion by the government that parents do not understand. The parents in this study were invested in their children's education and expressed perspectives that were consistent with those of scholars. This evidence was also supported by their day-to-day involvement in many aspects of their children's care, from clothing to food to nurture during care hours. So contrary to the Nigerian Curriculum, parents are very important stakeholders and contributors to their children's early learning. 


\section{References}

Aina, O. E. (2001). Maximizing learning in early childhood multiage classrooms: Child, teacher, and parent perceptions. Early Childhood Education Journal, 28(4), 219224.

Andero, A. A. (1994). Cultural approaches to education in nigeria. XLV(2), 68-74.

Ayling, P. (2015). Embodying "britishness": The (re)making of the contemporary nigerian elite child.Curriculum Inquiry, 45(5), 455.

Callaghan, K. (2013). The environment is a teacher. In Ontario. Ministry of Education. Think, feel, act: Lessons from research about young children, pp. 11-15. Toronto: Ministry of Education, Ontario.

Central Intelligence Agency. (2016). Nigeria. In The world factbook. Retrieved from https://www.cia.gov/library/publications/resources/the-world-factbook/geos/ni.html

Corter, C., \& Pelletier, J. (2015). Schools as integrated service hubs for young children and families: Policy implications of the toronto first duty project.International Journal of Child Care and Education Policy, 4(2), 45-54.

Creswell, J. W. (2014). Research design: Qualitative, quantitative, and mixed methods approaches (Fourth ed.) SAGE Publications.

Epstein, J. L. (2005). Attainable goals? The spirit and letter of the no child left behind act on parental involvement. Sociology of Education, 78(2), 179-182.

Epstein, J. L., \& Sanders, M. G. (1998). What we learn from international studies of school-family-community partnerships. Childhood Education, 74(6), 392-394.

Evans, M. P. (2013). Educating preservice teachers for family, school, and community engagement. Teaching Education, 24(2), 123-133. 
Federal Ministry of Education (2014). One year pre-primary school education curriculum.

Gallimore, R., Goldenberg, C., \& Weisner, T. (1993). The social construction and subjective reality of activity settings: Implications for community psychology. American Journal of Community Psychology, 21(4), 537-559.

Georgis, R., Gokiert, R. J., Ford, D. M., \& Ali, M. (2014). Creating inclusive parent engagement practices: Lessons learned from a school community collaborative supporting newcomer refugee families. Multicultural Education, 21(3), 23-27.

Gill, H., Lin, G., \& Purru, K. (2011). Politics, pedagogies and poetics of belonging: Negotiating differences between home and school communities/cultures. NUML Journal of Critical Inquiry, 9(1), 1-X.

Grace, R., Bowes, J., \& Elcombe, E. (2014). Child participation and family engagement with early childhood education and care services in disadvantaged australian communities. International Journal of Early Childhood, 46(2), 271-298.

Guo, Y. (2011). Beyond deficit paradigms: Exploring informal learning of immigrant parents. The Canadian Journal for the Study of Adult Education, 24(1), 41-59.

Guo, Y. (2012). Diversity in public education: Acknowledging immigrant parent knowledge. Canadian Journal of Education, 35(2), 120-140.

Hands, C. (2013). Including all families in education: School district-level efforts to promote parent engagement in ontario, canada. Teaching Education, 24(2), 134-149.

Ige, A. M. (2011). The challenges facing early childhood care, development and education (ECCDE) in an era of universal basic education in nigeria. Early Childhood Education Journal, 39(2), 161-167. 
Iyamu, E. O. S., \& Ogiegbaen, S. E. A. (2007). Parents and teachers' perceptions of mother-tongue medium of instruction policy in nigerian primary schools. Language, Culture and Curriculum, 20(2), 97-108.

Leithwood, K., \& Patrician, P. (2015). Changing the educational culture of the home to increase student success at school. Societies, 5(3), 664-685.

Lewis, L. L., Kim, Y. A., \& Ashby Bey, J. (2011). Teaching practices and strategies to involve inner-city parents at home and in the school.Teaching and Teacher Education, 27(1), 221-234.

McWayne, C. M., Melzi, G., Limlingan, M. C., \& Schick, A. (2016). Ecocultural patterns of family engagement among low-income latino families of preschool children. Developmental Psychology, 52(7), 1088-1102.

Ngwaru, J. M., \& Opoku-Amankwa, K. (2010). Home and school literacy practices in africa: Listening to inner voices. Language and Education,24(4), 295-307.

Nigerian Educational Research and Development Council (2004). National Early Childhood Curriculum (NECC) for Ages 0-5years.

Oluwafemi, O. L., Nma, A., Osita, O., \& Olugbenga, O. (2014). Implementation of early childhood education: A case study in nigeria. Universal Journal of Educational Research, 2(2), 119-125.

Ontario Ministry of Education. (2010). Parents in partnership: A parent engagement policy for Ontario schools. Retrieved from the Government of Ontario website: http://www.edu.gov.on.ca/eng/parents/involvement/PE_Policy2010.pdf

Onwuegbuzie, A. J., Dickinson, W. B., Leech, N. L., \& Zoran, A. G. (2009). A qualitative framework for collecting and analyzing data in focus group research. 
International Journal of Qualitative Methods, 8(3), 1-21.

Preston, J. P. (2013). Community involvement in school: Social relationships in a bedroom community. Canadian Journal of Education, 36(3), 413-437.

Purcell-Gates, V., Lenters, K., McTavish, M., \& Anderson, J. (2014). Working with different cultural patterns \& beliefs: Teachers \& families learning together.Multicultural Education, 21(3), 17-22.

Quezada, R. L. (2014). Family, school, \& community partnerships: Working with culturally diverse families. Multicultural Education, 21(3), 2-4.

Sanders, M. G., \& Epstein, J. L. (1998). International perspectives on school-family community partnerships. Childhood Education, 74(6), 340-341.

Shipley, C. D. (2013). Empowering children: Play-based curriculum for lifelong learning ( $5^{\text {th }}$ ed.) Nelson Education.

Sunal, C. S. (1989). Early childhood teachers in nigeria: Problems of quality and quanity. Childhood Education, 65(5), 279.

Tonyan, H. A., \& Nuttall, J. (2014). Connecting cultural models of home-based care and childminders' career paths: An eco-cultural analysis. International Journal of Early Years Education. 22(1), 117-138.

Underwood, K., \& Killoran, I. (2012). Parent and family perception of engagement: Lessons from early years programs and supports. Canadian Journal of Education, 35(4), 376-414.

van Oers, B. (2015). Implementing a play-based curriculum: Fostering teacher agency in primary school. Learning, Culture and Social Interaction, 4, 19-27. 
Walsh, G. M., McGuinness, C., Sproule, L., \& Trew, K. (2010). Implementing a play based and developmentally appropriate curriculum in northern ireland primary schools: What lessons have we learned? Early Years, 30(1), 53-66.

Wong, K. K. (2015). Implementing parent engagement policy in an increasingly culturally diverse community of new immigrants: How new is "new"? Canadian Journal of Education, 38(3), 1-30.

Yssel, N., Engelbrecht, P., Oswald, M., Eloff, I., \& Swart, E. (2007). Views of inclusion. Remedial and Special Education, 28(6), 356-365. 
Table 1. Number of participants by centre and session (pre and post intervention) Table 1

\begin{tabular}{l|l|l}
\hline & Centre One & Centre Two \\
\hline Pre intervention & $\mathrm{N}=4$ & $\mathrm{~N}=2$ \\
& & $\mathrm{~N}=3$ \\
\hline Post intervention & $\mathrm{N}=4$ & $\mathrm{~N}=8$ \\
& & $\mathrm{~N}=5$ \\
& & $\mathrm{~N}=8$ \\
\hline
\end{tabular}


Table 2. Thematic Data Analysis of Findings

Table 2

\begin{tabular}{|c|c|c|c|c|c|}
\hline \multirow[b]{2}{*}{ Theme } & \multirow[b]{2}{*}{ Category } & \multicolumn{2}{|c|}{$\begin{array}{c}\text { Pre } \\
\text { Intervention }\end{array}$} & \multicolumn{2}{|c|}{$\begin{array}{c}\text { Post } \\
\text { Intervention }\end{array}$} \\
\hline & & C1 & $\mathrm{C} 2$ & C1 & $\mathrm{C} 2$ \\
\hline \multirow{3}{*}{$\begin{array}{l}\text { Reasons for using } \\
\text { education system }\end{array}$} & Learning/education & 7 & 4 & 3 & 0 \\
\hline & Social interaction & 2 & 2 & 1 & 0 \\
\hline & Convenience & 1 & 5 & 0 & 0 \\
\hline \multirow{2}{*}{$\begin{array}{c}\text { Advocacy for } \\
\text { systematic/curricular } \\
\text { change }\end{array}$} & Teacher education/training & 6 & 3 & 6 & 1 \\
\hline & Curriculum/Program & 17 & 6 & 7 & 0 \\
\hline \multirow{2}{*}{$\begin{array}{l}\text { Understanding of play } \\
\text { based education }\end{array}$} & Learning through exp. & 1 & 4 & 9 & 2 \\
\hline & Play and learning & 14 & 3 & 11 & 2 \\
\hline \multirow{5}{*}{$\begin{array}{l}\text { Relationship/connection } \\
\text { between home and } \\
\text { school/care }\end{array}$} & Making learning visible & 4 & 2 & 3 & $\overline{3}$ \\
\hline & Environment & 5 & 7 & 2 & 2 \\
\hline & Communication & 5 & 4 & 12 & 1 \\
\hline & Relationship & 5 & 2 & 4 & 0 \\
\hline & Access & 2 & 6 & 6 & 0 \\
\hline
\end{tabular}

** C1 = site one: Private Christian School, $\mathrm{C} 2$ = site two: Government-run crèche 
Appendix A: Photograph

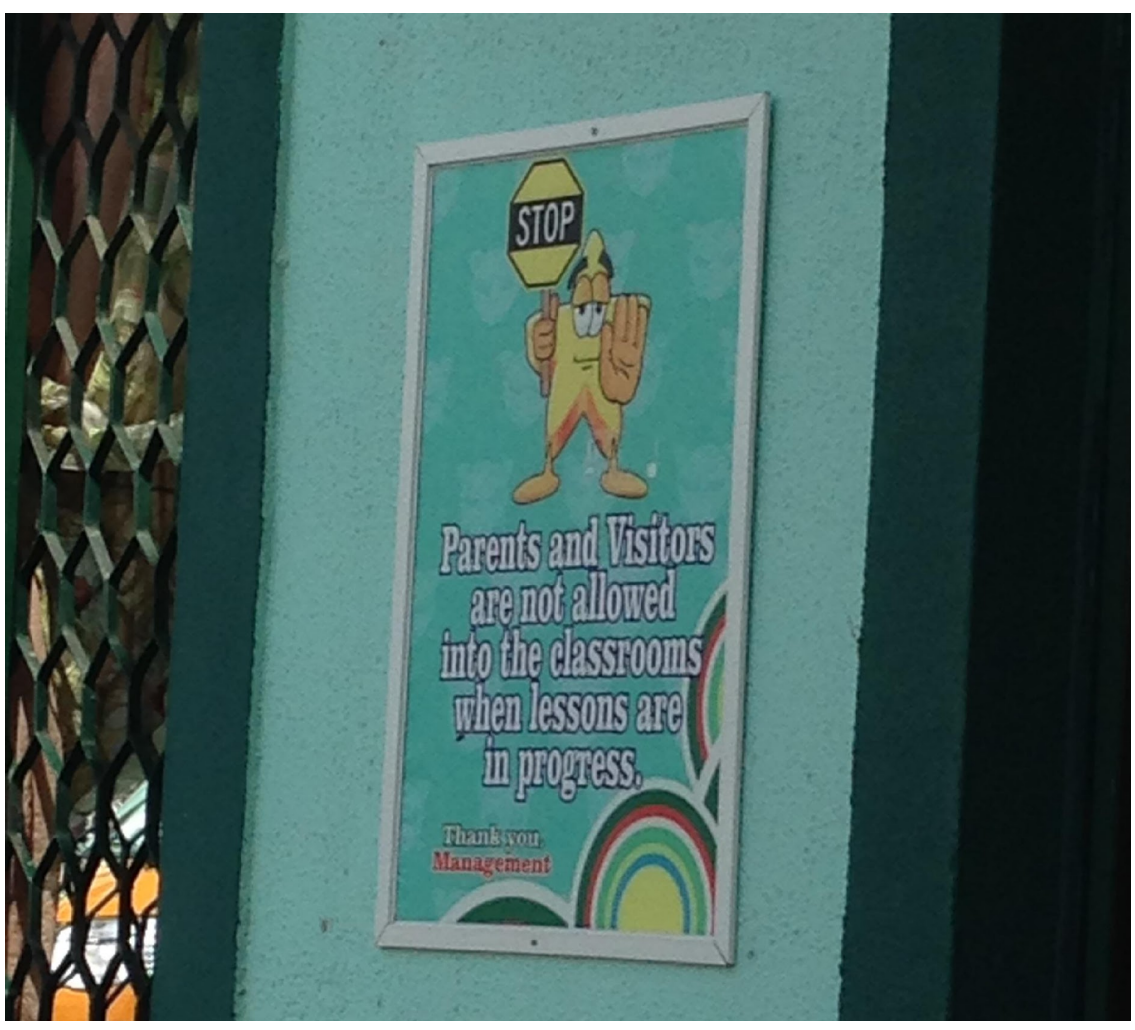




\section{Appendix B: Consent Form}

May 1, 2016

\section{Ryerson University, Toronto, Canada Consent Agreement}

You are being invited to participate in a research study. Please read this consent form so that you understand what your participation will involve. Before you consent to participate, please ask any questions to be sure you understand what your participation will involve.

The Introduction of Play to Nigerian Early Childhood Education (Parent and Child Form)

INVESTIGATORS: This research study is being conducted by Dr. Kathleen Peets, Associate Professor of Early Childhood Studies (ECS), Ryerson University, Patricia Falope, CEO of Early Childhood Development Initiative (ECDI) (a non-profit organization supporting teacher training in Nigeria), along with three masters students in ECS, Ryerson University: Jenna Santyr, Wendy Suh and Samantha Woolnough.

If you have any questions or concerns about the research, please feel free to contact Dr. Peets, 350 Victoria Street, KHS 350D, Toronto, ON, 416-979-5000 ext. 7646, kpeets@ryerson.ca.

PURPOSE OF THE STUDY: This study is to document the perspectives of all participants (children, parents, teachers) as they are introduced to a new play-based curriculum being delivered by ECDI, as well as to document the outcomes of this new curriculum after 4 weeks, and again in 4 months' time. We are asking all families whose children are between the ages of 2-6 years and who attend the childcare facility at the National Commission for Colleges of Education for theirs and their child's participation. The results of this study will help us to evaluate the way that we are training teachers to use play-based learning, and to use this information in setting up a teacher-training laboratory school in Abuja in 2017. The results will also be shared with people in the academic community at both Ryerson and beyond, including academic conferences and scholarly journal publications, and brief summaries will appear on the Ryerson website, the ECDI website and the faculty member's (Kathleen Peets) website. The results of this study will also serve to form the basis of Major Research Papers for the three graduate students listed above.

WHAT YOU WILL BE ASKED TO DO: If you volunteer to participate in this study yourself, and/or if you provide consent for your child to participate, you will be asked to do the following things over the 5-week study. The overall timeline of our work with your school community is as follows:

- Week 1 (May 23-27) for preparation and training of staff, visits to the school

- Weeks 2-4 (May 30-June 24) for working with staff in the schools 
- Follow up: October 24-28, 2016 for observation of how the program is going

Parent Participation: you will be asked to participate in a focus group with other parents in 2 sessions, fill out a questionnaire 3 times and participate in one-on-one interviews 3 times.

- Weeks 1 and 2:

o 30-minute focus group of 5 participants at the school/childcare facility, where you will be shown a video on learning from Canada to give you a sense of the kinds of activities we will be doing with your child, and we will ask for the group's reaction to this video.

- Questionnaire regarding your child's social and emotional development

- Weeks 2-5:

o 10-minute one-on-one interview at the school/childcare centre on the many ways that you use storytelling as a parent, and whether or not storytelling is useful in education.

- Parents will be asked for their opinions of what their children

- Week 5: should be learning and what role play has, if any, at school.

o Repetition of focus group, this time with a video of your own child engaged in the new activities that were developed for the project, and we will also ask for the group's reaction to this video

o Repetition of questionnaire regarding your child's social and emotional development

- Follow up:

o Repetition of questionnaire regarding your child's social and emotional development

Child Participation: we ask that your child participate in observations before and after the new curriculum is introduced, and during the curriculum to document some of the new activities that will be carried out, such as play-based learning and story activities. The observations will involve a combination of researchers writing notes, as well as using video- and audio-recording devices, with your consent (see form at the end of this document).

- Week 1: Observation

a. In order to determine how the new curriculum is working, Dr. Peets will observe each child while engaged in group activities: a broad developmental screen (Nippissing District Developmental Screen Plus) and a social-emotional behavioural checklist (Social Skills Checklist)

b. Observations will also be carried out by taking field notes and doing some videos of the new curriculum for us to examine later. One of the goals of looking at the videos is to see how learning is happening in math, literacy and other areas while the children are engaged in play.

- Weeks 2-5:

1. Child observations while they participate in the new curriculum 
c. Quiet observation, sometimes using a video camera or a still camera (see consent form)

d. There will be occasional questions to the children which will be recorded, such as "What is this game called?", "Did you learn anything new when you played that?"

e. A team member will ask to be included in the play once the children are familiar with her (after several days)

f. The observations will happen every day for the full length of the trial period, for varying amounts of time, but the direct interactions with children will happen for shorter durations such as 10-30 minutes at one time

2. Children's stories that will be audiorecorded (see consent form)

a. Children will be told stories and asked for their opinions - these stories will be a combination of Nigerian children's stories and international children's picture books

b. Children will be engaged in conversation and encouraged to tell both traditional stories and personal stories about their adventures, play with friends, interesting events, etc. For example, Dr. Peets might say "You know? One time I was having lunch and I was trying to carry everything on a tray at once. I was almost to the table and then my glass fell off the tray and made a big mess! Has anything like that ever happened to you?"

- Week 5: Repetition of the developmental screen and social-emotional behavioural checklist to see if the children's classroom interaction and behaviour have changed with the new curriculum.

- Follow-up: Repetition of the developmental screen and a social-emotional behavioural checklist to see if the children's classroom interaction and behaviour have changed or remained the same 4 months following the new curriculum.

All of the research findings that we have before we leave will be presented to parents formally at an information session that will include an oral presentation with visuals and film clips, and a question and answer session. We will also give a parent report to all families once the study is completed in October, 2016.

POTENTIAL BENEFITS: The potential benefits to the children for participating in the new curriculum are many, but the research study is not the actual curriculum it is the observation of it and yours and your child's participation in the focus groups, interviews, questionnaires, assessments and observations that make up the research part of the project. These activities may provide the benefits to you as parents in reflecting on your goals for your child and having a chance to share opinions with other parents and the research team. Your child may benefit from the stimulation of new interactions with the research team in play and storytelling, and they will receive a certificate and a book for their participation. But most of all, the benefits of the study are not direct - they are indirect. The indirect benefits of the 
study relate to research, education and society. The benefits to research are that we will learn about adapting a model of education cross-culturally in collaboration with Nigerian educators and stakeholders. There have been very few scientific studies of this type in Nigerian education, and this information will help us to understand education more broadly, child development and the Nigerian context, more specifically. Because the work is being carried out in collaboration with the Nigerian Ministry of Education, its impact will be far greater than at any one centre, and will lead to the establishment of a play-based teacher training laboratory school in Abuja. But to you and your children as participants, I cannot guarantee that there will be any benefit as a result of participating in the study.

WHAT ARE THE POTENTIAL RISKS TO YOU AS A PARTICIPANT: For many participants who have not yet been involved in a focus group or interview, the process may be embarrassing at times as you are asked for your opinions in a formal setting. We understand this and have worked with many people in this situation, and we try to ensure that comfort is maintained by providing you with information to react to instead of always asking you questions, and by creating an informal tone that is more conversational. We also avoid asking questions that are too personal or that would put you in any kind of awkward position - our goal is to hear your thoughts on early learning and play, and that is all. For children, they may be embarrassed as well by all of the attention from our research team, or they may be shy to participate or feel uncomfortable with cameras. Children may also disclose information of a personal nature that is sensitive during their storytelling, and if so, we will consult with centre administration as to how to react appropriately and for the benefit of the child. To address these risks, we are doing several things to help children to feel comfortable. First, we will introduce ourselves slowly to them, and gradually have them get to know us over several days before they see any cameras. We will explain to them why we are there and gradually learn their names and interact with them as participant-observers. We will also do activities with them at first that are not at all part of the research to enable them to get to know us. Secondly, we will show them the cameras before using them, and take some video together with them. We will ask them to give us a tour and show us their favourite places, and we will have them help us take pictures and videos of these places. When working with the children one-on-one we will ensure that they do not feel "evaluated" but that they know that they are helping to support research, and we will not emphasize "correct answers", but rather simply the interaction between Dr. Peets and each child. No participant, whether adult or child, will be required to respond or answer to any given question - this is always the choice of the participant. Furthermore, participants can skip questions that they do not wish to answer in any context (interview, questionnaire or focus group). Participants can also stop participation in the study at any time.

CONFIDENTIALITY: In any of the documents that we write based on this research study, we will not identify the name of the childcare centre or the names of any of the participants. We give parents the option of whether or not they or their child's 
name should be shared, and if so, under what circumstances, in the consent form (attached).

The data will be used for research and education purposes only by Ryerson University (the research team and Early Learning Centre at ECS) and ECDI. Results of the research will be shared in summary format only with stakeholders (UNICEF, World Bank, Nigerian Ministry of Education) for training and policy purposes, and no individual names or information will be shared with stakeholders at any time. The information collected during the study will be destroyed within two years (by October, 2018).

The transcriptions of audio recordings, audiorecordings, photographs and videorecordings will all be stored digitally and accessible only to the research team under password protection. Storage of data will be overseen solely by the two leads in the study, ECDI CEO Patricia Falope and Professor Kathleen Peets. Please see the detailed checkboxes at the end of this consent form to indicate which of these you give consent to use. We will show you the videos and transcripts of the audio before we use them for any purpose, to gain your approval of the use of this data.

VOLUNTARY PARTICIPATION AND WITHDRAWAL: Participation in this study is completely voluntary. You can choose whether to be in this study or not. If any question makes you or your child uncomfortable, you can skip that question. You or your child may stop participating at any time and you may also choose to not have your and/or your child's data included in the study. Your choice of whether or not to participate will not influence your future relations with Ryerson University, ECDI or the investigators Kathleen Peets, Patricia Falope, Jenna Santyr, Wendy Suh or Samantha Woolnough involved in the research.

QUESTIONS ABOUT THE STUDY: If you have any questions about the research now, please ask. If you have questions later about the research, you may contact Dr. Peets through the contact information provided at the beginning of this document. This study has been reviewed by the Ryerson University Research Ethics Board. If you have questions regarding your rights as a participant in this study please contact:

Research Ethics Board
c/o Office of the Vice President, Research and
Innovation
Ryerson University
350 Victoria Street
Toronto, ON M5B 2K3
416-979-5042
rebchair@ryerson.ca

Dr. Kathleen Peets

Associate Professor, Faculty of Community Services 


\section{THE INTRODUCTION OF PLAY TO NIGERIAN EARLY CHILDHOOD EDUCATION CONFIRMATION OF AGREEMENT:}

Your signature below indicates that you have read the information in this agreement and have had a chance to ask any questions you have about the study. Your signature also indicates that you agree to participate in the study and have been told that you can change your mind and withdraw your consent to participate at any time. You have been given a copy of this agreement.

You have been told that by signing this consent agreement you are not giving up any of your legal rights.

\section{i) Parent Participant}

Name of Participant (please print)

Signature of Participant

Date

Audio, Video, Photograph for Parent's Participation:

I agree to be the following types of recording for the purposes of this study.

Still Photograph $\square \quad$ Audiorecording $\square \quad$ Video recording $\square$

I understand how these recordings will be stored and destroyed.

Signature of Participant

Date

Permission to use name of institution or other identifying information. Please use/do not use my identifying information as follows:

YES NO

My first name:

Childcare facility name:

Signature of Participant

Date 
ii) Child Participant - to be signed by Parent/guardian of Participant - Third Party or Legal Representative

Signature of Participant or Parent/Guardian

Date

Name of Child (print) if applicable

Audio, Video, Photograph for Parent's Participation:

I agree to be the following types of recording for the purposes of this study.

Still Photograph $\square \quad$ Audiorecording $\square \quad$ Video recording $\square$

I understand how these recordings will be stored and destroyed.

Signature of Participant or Parent/Guardian

Date

Name of Child (print) if applicable

Permission to use name of institution or other identifying information of my child.

Please use/do not use my identifying information as follows:

YES

NO

My child's first name:

Childcare facility name:

Signature of Participant

Date 